\title{
Cocoa Extract Indicated Has Activity on Selectively Killing Breast Cancer Cells
}

\author{
Ariza Budi Tunjung Sari ${ }^{1^{*}}$, Mahriani ${ }^{2}$, Gusti Agung Perias Tiningrum ${ }^{2}$, Teguh Wahyudi ${ }^{1}$, Misnawi ${ }^{1}$
}

${ }^{1}$ Indonesian Coffee and Cocoa Research Institute (ICCRI), Jl. PB Sudirman 90, Jember 68118, East Java,

Indonesia, www.iccri.net, iccri@iccri.net

${ }^{2}$ Department of Biology, Faculty of Mathematics and Sciences, Jember University, Jl. Kalimantan 37, Jember 68121,

East Java, Indonesia

\section{ABSTRACT}

Effect of the cocoa crude extract on mortality of breast cancer cell lines i.e. MCF-7, T47D and normal cell (Vero), was observed. Crude cocoa extract prepared from a freshly dried cocoa bean that was containing $14 \%$ catechin and $0.6 \%$ caffeine. Catechin and caffeine content were modulated to 2 -folds ( $28 \%$ catechin or $1.2 \%$ caffeine) and 3 -folds ( $42 \%$ catechin or $1.8 \%$ caffeine) by adding pure compounds. Extracts were dissolved in dimethylsulfoxide (DMSO) at concentrations ranging from 200 to $1600 \mu \mathrm{g} / \mathrm{ml}$. The positive control was doxorubicin (0.5-16 $\mu \mathrm{g} / \mathrm{ml}$ in DMSO). Cell lines (MCF-7, T47D, and Vero) were incubated in test sample for $24 \mathrm{~h}$ at $37^{\circ}$, prior to 3-(4,4-dimetylthiazole-2-yl)-2,5-diphenyltetrazolium bromide (MTT) assay. The absorbance of each well was measured at $550 \mathrm{~nm}$, and lethal concentration (LC50) was calculated. The cocoa extract induced mortality of breast cancer cell lines but not in Vero cells. The effect on MCF-7 was greater than on T47D, given the LC50 was $1236 \mu \mathrm{g} / \mathrm{ml}$ (MCF-7) and $1893 \mu \mathrm{g} / \mathrm{ml}$ (T47D). Cytotoxic potential of cocoa extract was much lower than doxorubicin whose LC50 was $0,777 \mu \mathrm{g} / \mathrm{ml}$ (MCF-7) and 0,082 $\mu \mathrm{g} / \mathrm{ml}$ (T47D). Increasing catechin content to 2-folds did not significantly affect LC50 value, but 3-folds catechin content reduced LC50 to $1021 \mu \mathrm{g} / \mathrm{ml}$. Meanwhile increasing caffeine content to 2 -folds significantly reduced LC50 to $750 \mu \mathrm{g} / \mathrm{ml}$, however, 3-fold content resulted in slightly higher LC50 at $780 \mu \mathrm{g} / \mathrm{ml}$. This indicates that cocoa extract have anti-cancer potential, and purification may improve this property.

Keywords: breast cancer, cocoa, cytotoxicity, MCF-7, T47D

\section{INTRODUCTION}

Statistics revealed 32.6 million people ever lived with cancer, and 8.2 million died due to cancer in 2012. The numbers are increasing from 2008 whereas 7.6 million cancer-related deaths occurred. It is estimated that 14.1 million cases arose in 2012, compared with 12.7 million cases in 2008. Breast cancers account for $11.9 \%$ cases among diagnosed cancers, in which data from 2008-2012 showed increasing 20\% incidence and $14 \%$ mortality [1]. Smoking, alcohol consumption, and imbalance diet are among main factors [2]. Options for treatment fall into three categories i.e. surgical treatment (breast-conserving surgery and mastectomy), radiation and chemotherapy. Those therapies indeed carry side effects such as lymphedema, chest discomfort, impaired fertility, premature menopause and a

${ }^{*}$ Corresponding author: Ariza Budi Tunjung Sari Indonesian Coffee and Cocoa Research Institute (ICCRI) Jl. PB. Sudirman 90, Jember 68118, East Java, Indonesia E-mail: ariza.bts@gmail.com higher risk of osteoporosis [3].

To improve the chance of combating cancers, and to reduce the feeling of sickness following therapy, cancer patients seek for complementary and alternative medicines, in which most of them incorporate herbal extract [4]. Green tea, phytoestrogens, and mistletoe are among frequently used herbs [5] while breast cancer survivors also supplement with flaxseed, vitamin $\mathrm{C}$ and vitamin $\mathrm{E}$ [6]. The anti-cancer potency of plants extract is due to secondary metabolites, particularly terpenoids and phenolic compounds, that promote sensitivity and prevent the resistance of cancerous cells towards conventional therapies [7].

Cocoa is cultivated in southern hemisphere countries, to be consumed mostly by northern hemisphere population. The production is continually enhanced to overcome escalating consumption [8]. Cocoa provides a significant amount of phenolic and methylxanthine compounds that have been employed as an anti-inflammatory and stimulatory agent $[9,10]$. This study aims 
to observe the activity of cocoa extract in inducing cancer cells death, and to compare with doxorubicin as a chemotherapy agent. The composition of two secondary metabolites (catechin and caffeine) were modulated to determine the putative anti-cancer compound.

\section{MATERIALS AND METHODS}

Cocoa extract (CE) powder (Theobroma cacao L.) was obtained from Indonesian Coffee and Cocoa Research Institute. MCF-7, T47D and Vero cell lines cultures were obtained from Gajah Mada University, Yogyakarta. Reagents and solutions were Trypsin-EDTA 1x (Gibco), RPMI 1640 medium (Gibco), FBS (Fetal Bovine Serum) (Gibco), 0.5\% fungizone (Gibco), 2\% penicillin-streptomycin (Gibco), MTT (3-(4,5 dimetiltiazol-2-yl) -2,5 diphenyl tetrazolium bromide) (Sigma), DMSO (Dimethyl Sulfoxide) (E-Merck), SDS (Sodium Dodecyl Sulphate), HCl (E-Merck), PBS (Phosphate Buffer Saline). Other chemicals are doxorubicin (Kalbe), catechin (Sigma) and caffeine (Merck).

\section{Cocoa Extract Preparation}

CE was prepared by soaking cocoa powder (fat removed, unroasted, unfermented) in ethanol for overnight. The liquid was filtered and was concentrated by using vacuum evaporator to result in CEE powder. CEE containing $14 \%$ catechin (assayed by Folin-ciocalteu's reagent [11]) and 0,6\% caffeine (assayed using acid-base chromatographic column [12]).

\section{Cell Culture and Sample Preparation}

Cells were grown in RPMI 1640 medium containing 2\% Penicillin-streptomycin, $0.5 \%$ fungizone, and $10 \%$ FBS. Cells were distributed in 96-well microtiter plate at density $2 \times 104$ cells $/ \mathrm{ml}$ and allowed to attach during incubation at $37^{\circ} \mathrm{C}$ for $24 \mathrm{~h}$ under the presence of $\mathrm{CO} 2$. The test samples were prepared by dissolving $10 \mathrm{mg}$ CE in $50 \mathrm{ml}$ DMSO and $950 \mathrm{ml}$ culture medium. The solution was gradually diluted in medium, to reach concentration $600,800,1000,1200$, 1400, and $1600 \mu \mathrm{g} / \mathrm{ml}$. Cocoa extract was modified by adding pure catechin, so the final concentration is $28 \%$ (CE-cat2) and 42\% (CE-cat3). Caffeine was also added to crude extract to concentration $1.2 \%$ (CE-caf2) and $1.8 \%$ (CE-caf3). The modified extract was prepared in a similar manner with crude extract with concentrations at $600,1000,1400$, and $1800 \mu \mathrm{g} / \mathrm{ml}$. Doxorubicin as the positive control was dissolved in DMSO and culture medium with concentration ranges from $0.25-8$ $\mu \mathrm{g} / \mathrm{ml}$.

\section{Cell Viability Assay}

Cytotoxic activity were evaluated through MTT assay described by Hamedeyazdan et al. [13]. Briefly, cells were separately incubated in the presence of CE, modified extracts, or doxorubicin at $37^{\circ} \mathrm{C}$ for $24 \mathrm{~h}$. After removing the medium, cells were washed with PBS solution prior receiving 3-(4,5 dimetiltiazol-2-yl) -2,5 diphenyl tetrazolium bromide (MTT) reagent and incubated for another four hours. MTT reaction was stopped by addition of $10 \%$ SDS in $0.01 \mathrm{~N} \mathrm{HCl}$. The absorbance value was read at $550 \mathrm{~nm}$ wavelength using ELISA reader.

Tests were done triplicate. A concentration that result cells death by $50 \%$ population (IC50) was estimated from probit analysis by using SPSS 18 statistical software.

\section{RESULTS AND DISCUSSION Cytotoxicity of ethanolic cocoa extract}

CE induced cytotoxicity in MCF-7 cells while demonstrated weak toxicity on T47D cells. The initial concentration of $600 \mu \mathrm{g} / \mathrm{ml}$ has already resulted in mortality $33 \pm 5,2 \%$ of MCF-7 cells, while, at the same concentration, T47D cell death was $1.15 \pm 5.13 \%$. Increasing $\mathrm{CE}$ concentration significantly enhanced MCF-7 cells mortality ( $p<0,01, \alpha=0,05)$. The concentration of $1600 \mu \mathrm{g} / \mathrm{ml}$ resulted in cell death more than $50 \%$ population of MCF-7 cells, but for T47D cells the mortality was only $37 \pm 2.2 \%$ [Figure 1 ].

Vero cells representing normal cell lines were mildly affected by the presence of CE. At concentration $900 \mu \mathrm{g} / \mathrm{ml}$, CE induced $14 \pm 6,5 \%$ Vero cells death. The

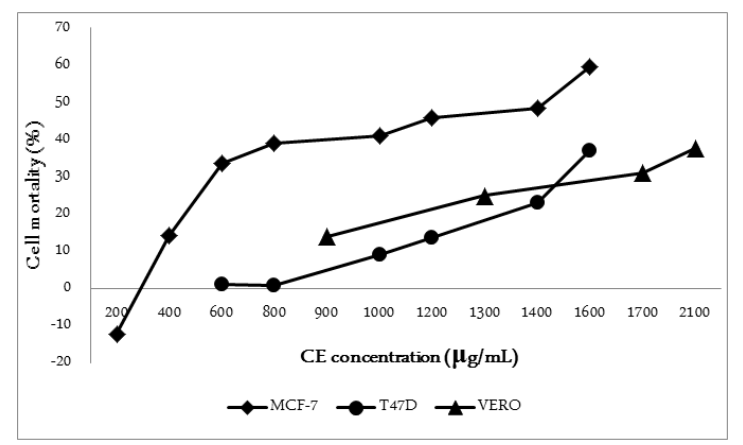

Figure 1. Effect of CE on MCF-7, T47D, and Vero cells mor tality. Cells were incubated for $24 \mathrm{~h}$ with various concentrations of CE $(200-2100 \mu \mathrm{g} / \mathrm{mL})$. The figure shows in general CE induced mortality of cells, however, concentration initiating cell death varied depending on cell lines. The mortality rate in each cell lines depends on concentration. 
viability of Vero cells exceeded $50 \%$ even after incubation in CE at very high concentration $(2100 \mu \mathrm{g} / \mathrm{ml})$. This data indicates the selectivity of $\mathrm{CE}$ towards breast cancer cells, particularly MCF-7, over normal cells.

\section{Anticancer Potential of Cocoa Extract}

The concentration that inhibits $50 \%$ viable cells (IC50) of CE was $1236 \mu \mathrm{g} / \mathrm{ml}$ against MCF-7. The value could not be calculated for T47D and Vero cells since $\mathrm{CE}$ was unable to induce $50 \%$ mortality even at high concentration. The positive control, doxorubicin, exhibited IC50 value $0,07 \mu \mathrm{g} / \mathrm{ml}$, which is 1600 -fold greater than CE.

\section{Modulation of Catechin and Caffeine Concentration Affected Cytotoxic Potential}

Higher catechin and caffeine content in $\mathrm{CE}$ increased cytotoxic potential. At concentration 600 $\mu \mathrm{g} / \mathrm{ml}$, MCF-7 cells mortality was increased from $33 \pm 5,2 \%$ to $40 \pm 2,2 \%$ when catechin content was 2 -fold, and to $48 \pm 1,7 \%$ at 3 -fold. The same manner observed when caffeine content was increased from the initial concentration $(33 \pm 5,21 \%)$ to 2 -fold $(47 \pm 1,8 \%)$ and 3 fold $(40 \pm 5,7 \%)$. Catechin augmentation may improve IC50 value from $1236 \mu \mathrm{g} / \mathrm{ml}$ to $1208 \mu \mathrm{g} / \mathrm{ml}$ and 1021 $\mu \mathrm{g} / \mathrm{ml}$. On the other hand, increasing caffeine content to 2 -fold may enhance IC50 to $750 \mu \mathrm{g} / \mathrm{ml}$, however, 3fold caffeine resulted in a slightly higher IC50 780 $\mu \mathrm{g} / \mathrm{ml}$ [Figure 2]. This research suggests caffeine plays a major role in the cytotoxic activity of CE towards MCF-7 cells.

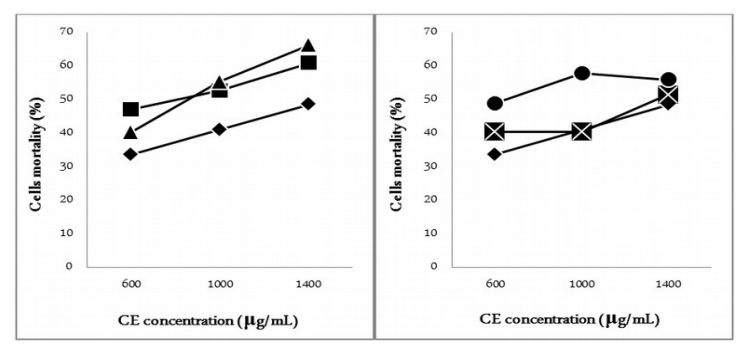

Figure 2. MCF-7 cells mortality (\%) after incubation in CE for $24 \mathrm{~h}$ at various catechin and caffeine content; innitial CE (catechin 14\%, caffeine 0,6\%), 2-fold catechin, $\mathbf{\Delta}_{3}$-fold catechin, $\mathbf{X}_{2}$-fold caffeine, and $\mathbf{~} 3-^{-}$ fold caffeine content. The figure shows cells mortality under effect of secondary metabolite, whereas cytotoxicity was enhanced by increasing catechin and caffeine content to 2 and 3-fold. However IC50 values were mostly affected by caffeine rather than by catechin.
Cytotoxic potential of CE is lower than other plant extracts such as Mangifera indica kernel $(15 \mu \mathrm{g} / \mathrm{ml})$, Elephantopus scaber $(14,69 \mu \mathrm{g} / \mathrm{ml})$ and Dillenia suffruticosa $(76 \mu \mathrm{g} / \mathrm{ml})$ [14-16]. However CE is stronger than Argyreia nervosa leaf $(>2500 \mu \mathrm{g} / \mathrm{ml})$, Dypterocarpus turbinatus leaf $(>2500 \mu \mathrm{l} / \mathrm{ml})$, and Saraca asoca leaf $(>2500 \mu \mathrm{g} / \mathrm{ml})$ [17]. There are reports from other studies that MCF-7 cells is more sensitive than T47D cells. Both cancer cells are attributed to estrogen-sensitive proliferation; cancer treatments target thus estrogen receptor. Resistant cells alters estrogen receptor expressions [18] while the expressions were increased in resistant MCF-7 cells, it is found to be negative or unchanged in resistant T47D cells. Estrogen receptor expression affects the sensitivity of cells towards tamoxifen or fulvestrant, whereas MCF-7 was more sensitive than T47D cells [18]. Further investigation by Brandie et al. [19] indicates that T47D cells tolerate cellular stress better than MCF-7 cells.

Cancer therapies attempt to induce programmed death in cancer cells. It is approached by either intrinsic or extrinsic apoptotic pathway. As an important drug for breast cancer therapy, doxorubicin mode of action is promoting cellular stress that leads to death through several mechanisms i.e. inhibiting topoisomerase II enzyme, forming doxorubicin-DNA adduct, stimulating oxidative stress, and increasing ceramide production that sensitizes cancer cells [20-22]. Furthermore, Yang et al. [23] suggested that doxorubicin is more likely altering DNA topography, by enhancing nucleosome turnover around promoter gene and triggering DNA instability.

Anti-cancer properties of catechin are associated with inhibition of proliferation and induction of apoptosis. Studies showed catechin regulates apoptosis through downregulation of anti-apoptotic protein $\mathrm{Bcl}-2$ and survivin, while upregulating pro-apoptotic protein Bax [24]. In the other hand, catechin suppresses cell proliferation by inhibiting nuclear factor KB (NF-KB) activation, vascular endothelial growth factor (VEGF) expression, and protecting from reactive oxygen species (ROS) stimulation [25-27]. Schlachterman et al. [28] reported that catechin along with resveratrol and quercetin, could be incorporated in a diet, to reduce breast tumor growth.

Caffeine has long history as an agent to sensitize cancer cells against ionizing radiation [29,30]. It has been investigated for cell cycle modulation and DNA damage signals over-riding [31,32]. Caffeine was also reported to stimulate apoptotic cells either through p53-dependent or p53-independent pathways since it 
enhanced UV-induced cell death in wild-type mice as well as in p53-knockout mice [33,34]. Besides, caffeine also induces autophagy, when it is found to increase autophagic vacuoles in SH-SY5Y cells at 10 or $25 \mathrm{mM}$. The level of microtubule-associated protein 1-light chain-3 (LC3) II as the autophagosomal marker was elevated, and this was associated with PI3K/Akt /mTOR/p70S6K pathway inhibition [35].

Greater cytotoxic potential exhibited in CE containing a higher concentration of phytoalexin compound suggests that purification may improve its anti-cancer properties. Lower IC50 value resulted from higher caffeine content instead of catechin indicates the purification method should consider preserving methylxanthine as a polar constituent, rather than semi-polar flavonoid. Even though IC50 of CE is much lower than doxorubicin and other plant extract, CE might be utilized as an anti-cancer agent by using it as a preventive or co-treatment agent. To validate anticancer property of $\mathrm{CE}$, an investigation of immunomodulatory properties, cell sensitization and co-administration with doxorubicin are required.

\section{CONCLUSIONS}

This research confirmed the cytotoxic potential of the cocoa extract against breast cancer cells. The effect is more pronounced in MCF-7 cells instead of T47D cells. High concentration of $\mathrm{CE}$ induced very low Vero cells mortality, indicating the selectivity of $\mathrm{CE}$ on cancerous cells rather than normal cells. Augmentation of phytoalexin constituent lowered IC50 value of CE, whereas caffeine gave greater effect than catechin.

\section{REFERENCES}

1. IARC (2013) Latest world cancer statistics, global cancer burden rises to 14.1 million new cases in 2012, marked increase in breast cancers must be addressed. Press Release. pp. 1-3.

2. Danaei G, Vander Hoorn S, Lopez AD, Murray CJ, Ezzati $\mathrm{M}$ (2005) Causes of cancer in the world: comparative risk assessment of nine behavioural and environmental risk factors. The Lancet. 366: 1784-1793.

3. Siegel R, DeSantis C, Virgo K, Stein K, Mariotto A, et al. (2012) Cancer treatment and survivorship statistics, 2012. CA A Cancer Journal for Clinicians. 62: 220-241.

4. Molassiotis A, Fernadez-Ortega P, Pud D, Ozden G, Scott JA, et al. (2005) Use of complementary and alternative medicine in cancer patients: a European survey. Annals of Oncology. 16: 655-663.

5. Olaku O, White JD (2011) Herbal therapy use by cancer patients: a literature review on case reports. European
Journal of Cancer. 47: 508-514.

6. 6. Boon HS, Olatunde F, Zick SM (2007) Trends in complementary/alternative medicine use by breast cancer survivors: comparing survey data from 1998 and 2005. BMC Women's Health.7: 4.

7. Wink M, Ashour ML, El-Readi MZ (2012) Secondary metabolites from plants inhibiting $\mathrm{ABC}$ transporters and reversing resistance of cancer cells and microbes to cytotoxic and antimicrobial agents. Frontiers in Microbiology. 3: 115.

8. ICCO (2012) The world cocoa economy: past and present. Executive committee 146th meeting: International Cocoa Organization. pp. 43.

9. Murphy KJ, Chronopoulos AK, Singh I, Francis MA, Moriarty $\mathrm{H}$, et al. (2003) Dietary flavanols and procyanidin oligomers from cocoa (Theobroma cacao) inhibit platelet function. The American journal of clinical nutrition. 77: 1466-1473.

10. Radin D, Hayssen G, Walsh J (2007) Effects of intentionally enhanced chocolate on mood. Explore: The Journal of Science and Healing. 3: 485-492.

11. Anesini C, Ferraro GE, Filip R (2008) Total polyphenol content and antioxidant capacity of commercially available tea (Camellia sinensis) in Argentina. Journal of Agricultural and Food Chemistry. 56: 9225-9229.

12. EC (1979) Laying down community methods for analysis for coffee extracts and chicory extracts. Official Journal of European Communities. 327: 18-28.

13. Hamedeyazdan S, Fathiazad F, Sharifi S, Nazemiyeh H (2012) Antiproliferative activity of Marrubium persicum extract in the MCF-7 human breast cancer cell line. Asian Pacific Journal of Cancer Prevention. 13: 5843-5848.

14. Abdullah A-SH, Mohammed AS, Abdullah R, Mirghani ME, Al-Qubaisi M (2014) Cytotoxic effects of Mangifera indica L. kernel extract on human breast cancer (MCF-7 and MDA-MB-231 cell lines) and bioactive constituents in the crude extract. BMC Complementary and Alternative Medicine. 14: 199.

15. Wan YH, Swee KY, Chai LH, Abdul RR, Abdul AS, et al. (2011) Elephantopus scaber induces cytotoxicity in MCF-7 human breast cancer cells via p53-induced apoptosis. Journal of Medicinal Plants Research. 5: 5741-5749.

16. Armania N, Yazan LS, Ismail IS, Foo JB, Tor YS, et al. (2013) Dillenia suffruticosa extract inhibits proliferation of human breast cancer cell lines (MCF-7 and MDA-MB231) via induction of $\mathrm{G} 2 / \mathrm{M}$ arrest and apoptosis. Molecules. 18: 13320-13339.

17. Akter R, Uddin SJ, Grice ID, Tiralongo E (2014) Cytotoxic activity screening of Bangladeshi medicinal plant extracts. Journal of natural medicines. 68: 246-252.

18. Lykkesfeldt A, Yde C, Thrane S, Larsen S, Pedersen A, et 
al. (2013) Abstract P5-09-02: Cell culture models to study mechanisms for endocrine resistant breast cancer, new treatment options and new biomarkers. Cancer Research 73: P5-09-02-P05-09-02.

19. Brandie NR, Margarita MI, Huy XM, Joshua KS, Bradford GH, et al. (2015) Bioenergetic differences between MCF-7 and T47D breast cancer cells and their regulation by oestradiol and tamoxifen. Biochemical Journal 465: 4961.

20. Pritchard JE, Dillon PM, Conaway MR, Silva CM, Parsons SJ (2012) A mechanistic study of the effect of doxorubicin/adriamycin on the estrogen response in a breast cancer model. Oncology 83: 305-320.

21. Yang F, Teves SS, Kemp CJ, Henikoff S (2014) Doxorubicin, DNA torsion, and chromatin dynamics. Biochimica et Biophysica Acta (BBA)-Biomembranes 1845: 84-89.

22. Swift LP, Rephaeli A, Nudelman A, Phillips DR, Cutts SM (2006) Doxorubicin-DNA adducts induce a nontopoisomerase II-mediated form of cell death. Cancer Research 66: 4863-4871.

23. Yang F, Kemp CJ, Henikoff S (2013) Doxorubicin enhances nucleosome turnover around promoters. Current Biology 23: 782-787.

24. Papademetrio DL, Trabucchi A, Cavaliere V, Ricco R, Costantino S, et al. (2013) The catechin flavonoid reduces proliferation and induces apoptosis of murine lymphoma cells LB02 through modulation of antiapoptotic proteins. Revista Brasileira de Farmacognosia 23: 455-463.

25. Rodríguez ML, Estrela JM, Ortega Á (2013) Natural Polyphenols and Apoptosis Induction in Cancer Therapy. Journal of Carcinogenesis and Mutagenesis 6: 1-10.

26. Gu J-W, Makey KL, Tucker KB, Chinchar E, Mao X, et al. (2013) EGCG, a major green tea catechin suppresses breast tumor angiogenesis and growth via inhibiting the activation of HIF-1 $\alpha$ and NFKB, and VEGF expression. Vascular Cell 5: 9.

27. Rathore K, Choudhary S, Wang H-CR (2012) Green tea catechin intervention of reactive oxygen species-mediated ERK pathway activation and chronically induced breast cell carcinogenesis. Carcinogenesis 33: 174-183.

28. Schlachterman A, Valle F, Wall KM, Azios NG, Castillo L, et al. (2008) Combined resveratrol, quercetin, and catechin treatment reduces breast tumor growth in a nude mouse model. Translational Oncology 1: 19-27.

29. Sarkaria JN, Busby EC, Tibbetts RS, Roos P, Taya Y, et al. (1999) Inhibition of ATM and ATR kinase activities by the radiosensitizing agent, caffeine. Cancer Research 59: 4375-4382.

30. DeFrank JS, Tang W, Powell SN (1996) p53-null cells are more sensitive to ultraviolet light only in the presence of caffeine. Cancer Research 56: 5365-5368.

31. Bode AM, Dong Z (2007) The enigmatic effects of caffeine in cell cycle and cancer. Cancer Letters 247: 26-39.

32. Kawabe T (2004) G2 checkpoint abrogators as anticancer drugs. Molecular Cancer Therapeutics 3: 513-519.

33. Lu Y-P, Lou Y-R, Li XH, Xie JG, Brash D, et al. (2000) Stimulatory effect of oral administration of green tea or caffeine on ultraviolet light-induced increases in epidermal wild-type p53, p21 (WAF1/CIP1), and apoptotic sunburn cells in SKH-1 mice. Cancer Research 60: 4785-4791.

34. Lu Y-P, Lou Y-R, Peng Q-Y, Xie J-G, Conney AH (2004) Stimulatory effect of topical application of caffeine on UVB-induced apoptosis in the epidermis of $\mathrm{p} 53$ and Bax knockout mice. Cancer Research 64: 5020-5027.

35. Saiki S, Sasazawa Y, Imamichi Y, Kawajiri S, Fujimaki T, et al. (2011) Caffeine induces apoptosis by enhancement of autophagy via $\mathrm{PI} 3 \mathrm{~K} / \mathrm{Akt} / \mathrm{mTOR} / \mathrm{p} 70 \mathrm{~S} 6 \mathrm{~K}$ inhibition. Autophagy 7: 176. 